\title{
The Policy of Education Based on Character Values for the Best Quality of Education "An Analysis of the Zoning System Policy Imposed by Ministry of Education and Culture in Indonesia"
}

\author{
Sarkadi ${ }^{*}$, Syifa Syarifa, Asep Rudi Casmana \\ Department of Pancasila and Civic Education, Faculty of Social Science, Universitas Negeri Jakarta, 13220, Indonesia
}

Received April 21, 2020 ; Revised May 27, 2020; Accepted June 26, 2020

Copyright $\odot 2020$ by authors, all rights reserved. Authors agree that this article remains permanently open access under the terms of the Creative Commons Attribution License 4.0 International License

\begin{abstract}
This study aims to analyse the zoning system policies regulated by The Ministry of Education and Culture Rule Number 44 Year 2019 about the policy of new student recruitment by referring to some character values in Government Policy Number 87 Year 2017 about the strengthening character education, namely democratic values, social care values and values of respect for achievement. The zoning system is a system of regulating the process of recruiting new students according to the area of residence. The system is regulated in Ministry or Education and Culture Rule No. 14 of 2018 and is intended so that no schools are considered favourite and non-favorite schools. The system won criticism because some students were even accepted into schools that had a greater distance than the nearest school. This study uses a quantitative approach with a survey method to determine respondents' assessments of zoning system policies as evaluation material. The results of this study indicate that the Zoning System Policy regulated in government law Number 44 of 2019 concerning the policy of new student recruitment is in accordance with character values such as democratic values, caring values and values of respecting achievement, even though they have not fulfilled the educational goals to the full. In terms of democratic values, the zoning system has succeeded in equitable distribution of education by providing easy access for students, eliminating educational disparities between urban and rural areas, eliminating the impression of favorite and non-favourite schools and improving the quality of education in Indonesia.
\end{abstract}

Keywords Policy, Zoning, Equity, Education, Character

\section{Introduction}

Education has been the right for everyone in Indonesia. It is because the education has become the basic right for Indonesian. The government has imposed a rule that at least, Indonesian citizens should have 12 years compulsory education. Then, the government has a regulation to support that policy. Basic constitution article 31 Paragraph 1 said that "Everyone has the right to education". This right is also regulated in the Universal Declaration of Human Rights Article 26. Therefore, education has become the right for everyone (Lee, 2013; Arwildayanto, Suking, \& Sumar, 2018)

The main purpose of education is to change the character of people and improve the adulthood (Thangeda, Baratiseng, \& Mompati, 2016). Thinking seriously about alternatives in education is a self-centred activity, where we can help our nation rediscover education that will serve us in the coming century (Levin, 1999). The government's effort to guarantee education in Indonesia is to issue an education policy. Educational policy is part of public policies that are applied in the field of education and are formulated to achieve national education goals (Sarkadi \& Casmana, 2020).

One of the educational policies stipulated in the framework of guaranteeing equal distribution of education in Indonesia is the enactment of the zoning system in the acceptance of new students as stipulated in Ministry of Education and Culture Rule Number 44 of 2019 concerning Acceptance of New Students (PPDB). Some of the objectives of implementing this system are to equalize access to equitable education services for students, to even out the quality of education, and to eliminate the impression of favourite schools and ordinary schools. 
However, in its implementation, the zoning system has not met its objectives optimally. This can be seen from a number of findings or research findings conducted by researchers relating to the implementation and evaluation of the zoning system. Purnawati (2018) in their study entitled Implementing New Student Admission Policies Based on the Zoning System in the City of Bandung, showed that the application of the zoning system was not effective if measured from indicators changing people's perceptions of favorite schools and reducing the number of discontinuing schools (Purwanti, Irawati, \& Adiwisastra, 2018; Zid, Casmana, \& Hijrawadi, 2020). Furthermore Hasbullah (2019) in their research entitled Evaluation of Zoning System Policies in Accepting New Students (PPDB) at the SMPN Level in Pamekasan District, shows that according to some sources most complaints were made about understanding the zoning limits, lack of socialization given through the village head and school principal (Hasbullah \& Anam, 2019). In addition, a study conducted by Nurailiyah (2019) entitled Policy Analysis of Zoning Systems Against Junior High School Student Behavior in Yogyakarta, showed that teachers complained about the behavior of students who were accepted based on the zonation pathways who did not have good learning motivation, lacked discipline, were busy in the classroom and come home from school prematurely (Nurlailiyah, 2019; Sumadi \& Casmana, 2020). In addition, the problem that often occurs next is the zoning system which prioritizes the distance of prospective students from schools compared to the national exam scores resulting in the collapse of the motivation of new learners in learning and achieving (Adiputra, Karsidi, \& Haryanto, 2019; Komarudin, Alkhudri, Ubedilah, Syaifudin, \& Casmana, 2019).

The results of other research conducted by Pradewi \& Rukiyati (2019), showed that: (1) zoning facilitates access to education services, (2) zoning equalizes the quality of schools, (3) zoning decreases the quality of schools, (4) zoning does not fit at the level SMA (senior high school), (5) zoning system restricts students from choosing schools, (6) zoning policies must be accompanied by equal distribution of educational facilities and infrastructure, and (7) zoning destroys diversity (Pradewi, 2019; Sarkadi, Casmana, \& Rahmawati, 2020). Then Marini \& Utoyo (2019), the results of his research show that the zoning system policy has helped reduce the gap between the two schools studied, because students who are accepted come from different circles, different from before which was only filled with capable students in terms of its achievements and economy (Marini \& Utoyo , 2019). However, the implementation of this system also has obstacles, quotas outside the zoning system affect the non-fulfilment of capacity in Bandar Lampung State High School, and the mindset of the community towards the quality of superior schools has not changed (Suhadi, Syafrudin, \& Casmana, 2020).
Based on the results of research conducted by several researchers regarding the implementation of zoning system policies. Broadly speaking, it can be said that the zoning system has not met the expected goals massively (Zid, Alkhudri, Casmana, Marini, \& Wahyudi, 2020). Therefore, there is a need for an analysis of the implementation of zoning system policies to find out what needs to be considered so that this system can be implemented well and able to achieve educational goals. To find out the implementation of Ministry of Education and Culture Rule Number 44 of 2019 in implementing GDP, researchers aim to conduct Ministry of Education and Culture Rule Number 44 Year 2019 policy analysis based on character values. The character values that are used as a reference are Presidential Regulation Number 87 Year 2017 Regarding Strengthening Character Education, Article 3, namely "...... religious, honest, tolerant, disciplined, hardworking, creative, independent, democratic, curiosity, the spirit of nationalism, love of the motherland, respect for achievement, communicative, love for peace, love to read, care for the environment, care for the social, and responsible ". Based on the background study mentioned above, this study would focus on the values chosen in this study which are democratic values, respect for achievement, and social care.

\section{Methods}

\section{Research Design}

This study used quantitative. The method was used to explain the participants' opinion holistically (Sugiyono, 2017). In addition, survey method is used to ask a wide range of opinion from several school policies regarding the zoning system (Creswell, 2008). In this study, the survey method is used to determine the assessment of the zoning system policies regulated in Ministry of Education and Culture Rule Number 44 of 2019 concerning Acceptance of New Students by referring to three character values namely; democratic values, values that value achievement and responsible values, as an evaluation for the government towards the implementation of policies. Therefore, the survey method is considered to be imperative for this study (Sugiono, 2017).

\section{Population and Sample}

Population is overall people or subject in some area or location (Sugiyono, 2017). It is an important aspect of this research, so that population should be explained very well. The population in this study is the school stakeholder in Indonesia, particularly in Jakarta, Bogor, Tangerang and Bekasi. The number of sample which has been taken from overall population is about 206 respondents. The majority of respondents are the school stakeholders, teachers as well 
as pre-service teachers from a reputable university. However, the most important aspect on choosing respondents is that they are understood regarding the education zoning system for a new student election.

\section{Data Collection}

The data collection process in this study focuses on online survey using questionnaire. The data in this study were obtained through a questionnaire technique. The questionnaire is a collection technique that is done by giving a set of data questions or written statements to the respondents, so that they can answer the questions easily (Sugiyono, 2017). The detail questionnaire given to the respondents is shown as follow:

Table 1. Research Instruments

\begin{tabular}{|c|c|}
\hline $\begin{array}{c}\text { Character Value } \\
\text { Indicator }\end{array}$ & Questions \\
\hline Democratic values & $\begin{array}{l}\text { 1. Zoning system applied is based } \\
\text { on current needs at Indonesia. } \\
\text { 2. The zoning system is in place } \\
\text { for the creation of equal } \\
\text { distribution of student smart } \\
\text { one. } \\
\text { The zoning system eliminates } \\
\text { the impression of favourite } \\
\text { school and not favourite. } \\
\text { The zoning system is in place } \\
\text { for improving the quality of } \\
\text { education nationally }\end{array}$ \\
\hline Social Care values & $\begin{array}{l}\text { 1. The zoning system is profitable } \\
\text { low-middle quality schools } \\
\text { down. } \\
\text { The zoning system takes care of } \\
\text { candidate's students to be } \\
\text { accepted at school the closest. } \\
\text { The zoning system does not } \\
\text { consider the quality of the } \\
\text { teacher in school. }\end{array}$ \\
\hline $\begin{array}{c}\text { Value of Appreciating } \\
\text { Achievement }\end{array}$ & $\begin{array}{l}\text { Most zoning systems are detrimental } \\
\text { to prospective students intelligent. }\end{array}$ \\
\hline
\end{tabular}

The questionnaire in the study is divided into three main parts, which are democratic values, care values, and appreciating achievements values. Firstly, in the democratic values, the majority of respondents are asked regarding the policy of education zoning system. In particular, the opinion which said that zoning system is applied based on the needs of Indonesian citizens, the zoning system is part of the creation of equal distribution of student. In addition, the democratic values also measure that zoning system can make students to remove the favourite school and improve the local quality of education.

Secondly, in the care values contains that the zoning system is whether profitable for the middle quality people. It means that the respondents are asked regarding the benefits of the zoning system for the middle-class family. Then, this value also measures the acceptance rate and the quality of the teacher in school. Thirdly, the appreciating achievement values measure the detrimental to the prospective students.

\section{Data Analysis}

Data analysis plays an important role in doing quantitative research. To analyse the data, it used descriptive statistic. It is a method for displaying the data in a group of presentation, so that the data will be easily to understand. The data is classified based on the activities that are undertaken in the research. This case is regarding the questionnaire relating to the zoning system.

The method of descriptive statistic only provides information about the data they have and in no way draw inference or any conclusions about the larger parent group (Creswell, 2008). In this case, the measure of centralization of the data used is the focus of the research instrument. In addition, there are tools or software used to help in the process of quantitative data analysis, namely SPSS. This software is an application used to carry out advanced statistical analysis, data analysis with machine learning algorithms, string analysis, and big data analysis that can be integrated to build a data analysis platform.

\section{Results and Discussions}

The zoning system in accepting new students is one of the new policies implemented by the government of the Republic of Indonesia. The form of regulations is made by the government through Minister of Education and Culture Regulation No. 51 of 2018 concerning the admission of new students. One of the main things that becomes the rule in accepting new students with this zoning system is that prospective students must study in a location close to their homes. The government policy produced pros and cons of the zoning system. This section will examine the results of research and discussion of the zoning system which is divided into three main parts, namely democratic values, care values and values of appreciating achievement.

\section{Democratic Values}

Selection of prospective new students is done by prioritizing the distance of the closest place of residence to the school in the specified zoning. The distance of the nearest residence is calculated based on the distance from the Village to the school. If the distance of residence is the same, then the priority is prospective students who register early. Generally, the zoning route has the highest quota of all revenue channels. For example, in East Java High School, the policy of new student recruitment (PPDB) the quota for zoning is 50 percent, while in DKI Jakarta PPDB the quota provided for zoning is 60 percent.

To find out the views and assessments of the community towards the implementation of Ministry of Education and 
Culture Rule Number 44 of 2019 concerning the policy of new student recruitment is based on character values. Value is something that is considered good, aspires to its existence and becomes a common goal in social life. Values are always associated with ethics, morals or manners (Sukitman, 2016). Meanwhile, character is a core component of humanity (Pradhan, 2009). Character is related to moral concepts (moral knowing), moral attitudes (moral feeling), and moral behavior (moral behavior) (Lickona, 1992). Based on the three components, it can be concluded that good character is supported by knowledge about goodness, the desire to do good, and do good deeds. Likewise with a policy. In formulating policies, there needs to be a commitment to do good for the community. The examples of character values listed in Presidential Regulation Number 87 of 2017 Article 3, regarding
Strengthening Character Education are: democratic values, values that value achievement and social care values.

Democratic values in this study are reviewed from how the zoning system policies are in accordance with democratic values such as prioritizing community needs, public welfare, eliminating discrimination and creating equality through equal distribution of education. Furthermore, the value of social care is in terms of how the zoning system policies care about the existence of educational inequality from the conditions of society and conditions between schools. Then the value of respecting achievement is evaluated from how the zoning system policy values the achievement of students in the implementation of PPDB.

Research that has been conducted shows the following results:

Table 2. Study results

\begin{tabular}{|c|c|c|c|}
\hline Indicator & Questions & Agree & Disagree \\
\hline $\begin{array}{l}\text { Democatic } \\
\text { values }\end{array}$ & $\begin{array}{l}\text { 1. Zoning system applied is based on current needs at } \\
\text { Indonesia. } \\
\text { The zoning system is in place for the creation of equal } \\
\text { distribution of student smart one. } \\
\text { 3. The zoning system eliminates the impression of } \\
\text { favourite school and not favourite. } \\
\text { 4he zoning system is in place for improving the } \\
\text { quality of education nationally }\end{array}$ & $\begin{array}{l}73,3 \% \\
72,3 \% \\
57,3 \% \\
76,2 \%\end{array}$ & $\begin{array}{l}26,7 \% \\
27,7 \% \\
42,7 \% \\
23,8 \%\end{array}$ \\
\hline $\begin{array}{l}\text { Social care } \\
\text { values }\end{array}$ & $\begin{array}{l}\text { 1. The zoning system is profitable middle quality } \\
\text { schools down. } \\
\text { 2. The zoning system takes care of candidate students to } \\
\text { be accepted at school the closest. } \\
\text { 3. The zoning system does not consider the quality of } \\
\text { the teacher in school. }\end{array}$ & $\begin{array}{l}75,7 \% \\
91,3 \% \\
48,1 \%\end{array}$ & $\begin{array}{l}24,35 \\
8,7 \% \\
51,9 \%\end{array}$ \\
\hline $\begin{array}{l}\text { Value of } \\
\text { Appreciating } \\
\text { Achievement }\end{array}$ & $\begin{array}{l}\text { Most zoning systems is detrimental to prospective students } \\
\text { intelligent. }\end{array}$ & $57,3 \%$ & $42,7 \%$ \\
\hline
\end{tabular}


Based on the results of the study, it can be said that as many as $73.3 \%$ of respondents agreed that zoning was implemented based on current needs in Indonesia. One of the objectives of the zoning system is to ensure equitable distribution of education in Indonesia which is a problem that must be resolved immediately. Initially, many children must take the test first to be accepted in certain schools and be rejected if their test results do not meet the standards. In fact, everyone has the right to obtain education. However, with the zoning system it is no longer valid. Schools that are labelled favourites may no longer conduct tests on the admission process of prospective new students, be they tests of reading, writing, or arithmetic (Sarafah \& Wibowo, 2018).

Then, as much as $72.3 \%$ of respondents agreed if the zoning system was put in place for the creation of an even distribution of intelligent students. The implementation of the zoning system can be one of the efforts to resolve educational disparities between urban and rural areas. Because, usually students who excel will choose a favorite school in urban areas even though he lives in the countryside. With the zoning system, students can attend schools that are not far from a place of residence that also has the same access to education. Furthermore, as many as $57.3 \%$ of respondents agreed that the zoning system could eliminate the impression of favorite schools and non-favorite schools, while some disagreed. This is because even though this zoning system has been put in place, the impression of favorite schools and non-favorite schools still exists in the minds of the public. Favorite schools have adequate facilities and infrastructure so that they can support the learning process of students. Conversely, schools that are considered not favorite do not yet have adequate facilities and infrastructure. An effort to equalize education in Indonesia not only by relying on the zoning system, but also the need for equal distribution of facilities and infrastructure supports the learning process for each school.

As many as $76.2 \%$ of respondents agreed that the zoning system was put in place to improve the quality of education nationally. The zoning program is an effective government program in the distribution of quality of education (Sarafah $\&$ Wibowo, 2018). During this time the distribution of education in Indonesia has experienced many problems, one of which is easy to access to educational services for students. During this time, prior to the zoning system, favorite schools tended to take advantage of business opportunities in the implementation of PPDB by setting a certain price for prospective students who registered. This is certainly very unfriendly to the condition of poor families who want to send their children to school even though they are close to where they live.

\section{The Social Care Values}

The zoning system also has values of concern for education and the conditions of people in Indonesia. This is indicated by as much as $75.7 \%$ of respondents agree that the zoning system benefits schools of lower to middle quality. Usually, schools that are considered quality (favorite) get more attention and assistance from the government as well as easy access for students to continue their education to a higher level. For example students from SMA X, which are favorite schools, have a greater opportunity to be accepted at State Universities (PTN) through the SNMPTN. With the zoning system, every school has the opportunity to improve its quality both by utilizing the distribution of intelligent students, as well as utilizing their local potential. The zoning system eliminates the impression of intelligent student monopoly, so this system eliminates educational inequality. Each school can show its own quality.

Furthermore, as many as $91.3 \%$ of respondents agreed that the zoning system cared about prospective students to be accepted at the nearest school. In this case, the zoning system aims to bring the education environment closer to the family and community environment. This system supports the implementation of Education Centres, namely the concept of education that empowers the educational environment, the family environment and the school environment in influencing the formation and inculcation of character values towards students. In addition, there will be no more parents who do not send their children to school because of cost constraints. Students with both high and low abilities have the right to be accepted in schools close to where they live.

As many as $51.9 \%$ of respondents disagreed that the zoning system was considered not to consider the quality of teachers in schools, while the rest agreed. Enforcement of the zoning system provides an opportunity for teachers to be able to show their quality. For example, a rural school does not mean to have a school teacher quality which is low. With the zoning system, teachers are also given the confidence to be able to adapt in teaching and educating students from various circles. For example teachers in favorite schools who normally teach students with high abilities, are now required to be able to adapt to students with low ability and responsibility to provide good teaching. However, it would be nice if the zoning system is also accompanied by standardization and equitable distribution of the quality and quantity of teachers by distributing teachers to schools that lack teachers.

\section{The Values of Appreciating Achievement}

Judging from the value of rewarding achievement, as much as $57.3 \%$, respondents agreed that the zoning system was largely detrimental to intelligent students, while the rest agreed. In terms of several cases, the implementation of the zoning system has drawn a lot of contra from the community because intelligent children cannot register at the intended school due to the distance of residence far 
from school even though they have satisfactory National Examination (UN) scores. Meanwhile, children who are less intelligent can be accepted at the intended school only because of the location of a residence close to the school. This in turn has led to new problems such as increased rates of displacement of residences near schools, as well as decreased learning motivation and enthusiasm for achievement of children due to school accepts students based on distance calculation from home to school, not calculation of UN scores or consideration of achievement. However, with the issuance of Ministry of Education and Culture Rule Number 44 of 2019, it has provided an opportunity for intelligent and high-achieving students to increase the achievement path quota from the original $15 \%$ (fifteen percent) to $30 \%$ (thirty percent) or double that. In addition, the prospective students' national exam scores can also be used as one of the categories of achievement pathways when registering at the intended school.

\section{Conclusions}

The results of this study indicate that the Zoning System Policy regulated in Ministry of Education and Culture Rule Number 44 of 2019 concerning PPDB is in accordance with character values such as democratic values, caring values and values of respecting achievement, even though they have not fulfilled the educational goals to the full. In terms of democratic values, the zoning system has succeeded in equitable distribution of education by providing easy access for students, eliminating educational disparities between urban and rural areas, eliminating the impression of favorite and non-favorite schools and improving the quality of education in Indonesia. Judging from the value of social care, the zoning system policy provides an opportunity for schools of middle to lower quality, caring for students to attend closest schools, and striving to consider the quality of teachers. Meanwhile, in terms of the value of appreciating achievement, the zoning system is considered to still not be able to appreciate the achievements of students in implementing PPDB. This is because the zoning system was initially thought to make learning motivation and enthusiasm for children's achievement decrease because schools only accept students based on distance calculation from home to school, not calculation of UN scores or consideration of achievement. However, Ministry of Education and Culture Rule No. 44 of 2019 has raised the achievement path quota as much as twice, from $15 \%$ to $30 \%$. At least the zoning system based on Ministry of Education and Culture Rule Number 44 of 2019 on the implementation of PPDB is still better than the previous policy.

In an effort to equalize the quality of education in Indonesia, it would also be good to be accompanied by equal distribution of facilities and infrastructures that support the learning process in each school and standardize and equalize the quality and quantity of teachers by distributing teachers to schools that lack teachers.

\section{REFERENCES}

[1] Adiputra, A. R., Karsidi, R., \& Haryanto, B. (2019). Stakeholder Perception about Zoning System of New Student Entrollment Programme (PPDB) at SMA Negeri 2 Sukoharjo in the Academic Year 2018/2019. Prosiding Seminar Nasional Pendidikan KALUNI, (pp. 466-479). Surakarta.

[2] Arwildayanto, Suking, A., \& Sumar, W. T. (2018). Analisis Kebijakan Pendidikan: Kajian Teoritis, Eksploratif, dan Aplikatif. Bandung: CV Cendeka Press.

[3] Cochran, C. L., \& Malone, E. F. (2014). Public Policy: Perspective and Choices Fifth Edition. Boulder, Colorado: Lynne Rienner Publisher.

[4] Creswell, J. W. (2008). ducational Research; Planning, Conducting, and Evaluating Quantitative and Qualitative Research. New Jersey: Pearson Education Inc.

[5] Dunn, W. N. (2003). Analisis Kebijakan Publik. Yogyakarta: Gadjah Mada University.

[6] Hasbullah, \& Anam, S. (2019). Evaluasi Kebijakan Sistem Zonasi Dalam Penerimaan Peserta Didik Baru (PPDB) Di Tingkat Sekolah Menengah Pertama Negeri (SMPN) Di Kabupaten Pamekasan. Reformasi, 112-122.

[7] Islamy, I. (2003). Prinsip-Prinsip Perumusan Kebijakan Negara. Jakarta: Bumi Aksara.

[8] Komarudin, Alkhudri, A. T., Ubedilah, Syaifudin, \& Casmana, A. R. (2019). The nationality education model: the implementation of a score-a training model for youth across different cultures in Indonesia. Journal of Social Studies Education Research, 10(2), 308-322.

[9] Lee, S. E. (2013). Education as a Human Right in the 21st Century. Democracy \& Education, 1-9.

[10] Levin, B. (1999). Educational Policy and Development. International Political Science Review, 385-395.

[11] Lickona, T. (1992). Educating for Character: How Our School Can Teach Respect and Responsibility. New York: Bantam Books.

[12] Lubis, S. (2007). Kebijakan Publik. Bandung: 2007.

[13] Madjid, A. (2018). Analisis Kebijakan Pendidikan. Yogyakarta: Penerbit Samudra Biru.

[14] Marini, K., \& Utoyo, B. (2019). Menimbang Kembali Kebijakan Sistem Zonasi: Studi Penerimaan Peserta Didik Baru di Bandar Lampung. Jurnal Administrativa, 87-100.

[15] Martitah. (2019). Zoning System of Education as a Strategy for Equalizing Education Quality in the Disruptive Era (Legal Aspect Review). 1st International Conference on Education, Social Sciences and Humanities (ICESSHum 2019) (pp. 32-36). Atlantis Press.

[16] Nurlailiyah, A. (2019). Analisisi Kebijakan Sistem Zonasi Terhadap Perilaku Siswa SMP di Yogyakarta. Realita, 
$13-21$.

[17] Okroma, N. S. (2006). Educational policies and problem of implementation in Nigeria. Australian Journal of Adult Learning, 242-263.

[18] Perdana, N. S. (2019). Implementasi PPDB Zonasi dalam Upaya Pemerataan Akses dan Mutu Pendidikan. Jurnal Pendidikan Glasser, 78-92.

[19] Perry, L. B. (2009). Conceptualizing Education Policy in Democratic Societis. Educational Policy, 423-450.

[20] Pradewi, G. I. (2019). Kebijakan Sistem Zonasi dalam Perspektif Pendidikan. JMSP (Jurnal Manajemen dan Supervisi Pendidikan), 28-34.

[21] Pradhan, R. K. (2009). Character, Personality and Profesionalism. Social Science International, 3-23.

[22] Prunty, J. J. (1985). Signpost for a Critical Educational Policy Analysis. Australian Journal of Education, 133-140.

[23] Purwanti, D., Irawati, I., \& Adiwisastra, A. (2018). Efektivitas Kebijakan Penerimaan Peserta Didik Baru Sistem Zonasi Bagi Siswa Rawan Melanjutkan Pendidikan. Dinamika, 1-7.

[24] Ramdhani, A., \& Ramdhani, M. A. (2017). Konsep Umum Pelaksanaan Kebijakan Publik. Jurnal Publik, 1-12.

[25] Sarafah, A. A., \& Wibowo, U. B. (2018). Program Zonasi di Sekolah Dasar Sebagai Upaya Pemerataan Kualitas Pendidikan di Indonesia. Lentera Pendidikan, 206-213.

[26] Sarkadi, \& Casmana, A. R. (2020). The Application of Empathetic Learning in Facing the Covid-19 Pandemic as the Responsibility of Good Citizens. International Journal of Psychosocial Rehabilitation, 24(9), 1475-7192.

[27] Sarkadi, Casmana, A. R., \& Rahmawati, Y. (2020). Improved Learning Design for Pre-Service Teacher in a Character Education Course. Universal Journal of Educational Research, 8(1), 212-224. DOI: 10.13189/ujer.2020.080126.

[28] Suhadi, Syafrudin, I., \& Casmana, A. R. (2020). The Political Culture of the Cigugur Society, Indonesia.
International Journal of Psychosocial Rehabilitation, 24(9), 1168-1175.

[29] Solichin, M. (2015). Implementasi kebijakan pendidikan dan peran birokrasi. Jurnal Studi Islam, 148-178.

[30] Sugiyono. (2011). Metode Penelitian Pendidikan Pendekatan Kualitatif dan R\&D. Bandung: Alfabeta.

[31] Sugiyono. (2016). Metode Penelitian Kombinasi (Mixed Methods). Bandung: C.V. Alfabeta.

[32] Sugiyono. (2017). Metode Penelitian Kuantitatif, Kualitatif, dan R\&D. Bandung: C.V. Alfabeta.

[33] Sukitman, T. (2016). Internalisasi Pendidikan Nilai Dalam Pembelajaran (Upaya Menciptakan Sumber Daya Manusia Yang Berkarakter). Jurnal Pendidikan Sekolah Dasar, 85-96.

[34] Sumadi, T., \& Casmana, A. R. (2020). The Importance of Social Competences Transformation towards Early Age Children in Jakarta. Universal Journal of Educational Research, $\quad$ 8(5), 1991-1996. DOI: 10.13189/ujer.2020.080536.

[35] Tachjan. (2006). Implementasi Kebijakan Publik. Bandung: Penerbit AIPI Bandung.

[36] Thangeda, A., Baratiseng, B., \& Mompati, T. (2016). Education for Sustainability: Qulaity Education Is a Necessary in Modern Day. How Far do the Educational Institutions Facilitate Quality Education? Journal of Education and Practice, 9-17.

[37] Zid, M., Casmana, A. R., \& Hijrawadi, S. N. (2020). The Development of International Education towards Migration Abroad by Indonesian Women. Universal Journal of Educational Research, 8(5), 1953-1963. DOI: 10.13189/ujer.2020.080532.

[38] Zid, M., Alkhudri, A. T., Casmana, A. R., Marini, A., \& Wahyudi, A. (2020). Ex Migrant Workers of International Women and Social Entrepreneurship: Study at Kenanga Village in Indramayu Regency in West Java Province in Indonesia. International Journal of Advanced Science and Technology, 29(06), 1855-1861. 